\title{
ARSACE, IL FAUT PARTIR
}

Sylvia Townsend Warner

(from English Story, 6th Series, Collins 1945)

Growing old, the body develops imperious idiosyncrasies, and for some years Odette de Boulay's body had obliged her to get up in the middle of the night and go to the orchard. The usual receptacle, said her brother Yves, would have sufficed any other woman. But not Odette. Odette must needs promenade herself like the Ankou, like a portent of death. At first there had been a show of pretexts, footsteps near the hen-house, the bull rattling his chain. But pretexts had been cast aside, the habit became a habit and nothing could alter it, not even the quartering of two occupying lieutenants.

'Now at least you will behave like a reasonable woman! You'll be arrested. You'll be shot.'

'On the contrary. I shall tell them I suffer from insomnia. They won't be able to say anything.' she added derisively. They are too correct.'

And indeed since they were under orders to behave as correctly as possible, and since Mademoiselle was the aunt of Clovis de Boulay, nothing was hinted or done to restrict the visits to the orchard. The two lieutenants, the captain who followed them, the chaplain who followed the captain, even the Todt personage who settled in as unobtrusively as a mildew, all correctly knew and correctly admired the regional novels of Clovis de Boulay, novels so expressive of the true, the traditional spirit of France. 
Habit persists, subjugating the will that first abetted it, habit becomes a ghost stalking through the deserted manor of the body. In her seventy-third year Odette might think better of an indoor chamber pot; but habit clawed her into the orchard where the winter frosts (though in the Cotentin the frosts are not so severe as those inland), were scarcely less chilling than the heavy dews of summer.

Now it was June. In another three months the apples would be falling. But many would fall before then, shrivelled and useless. It would be a bad apple year, the Ice Saints had come at their sharpest, and now it was not possible to ward off the spring frosts with bonfires. However carefully one covered the fire it might burst into flame and become a signal to the English bombers. So there would be few apples this year. Meanwhile the weather was changing. A wind swung the boughs, there was rain in the air, the moon ...

Inattentively, she glanced up to examine the moon. A cloud encompassed it. Only by force of habit interested in the moon she continued to stare at the cloud, which had a rim that recalled to her the ermine tippet she had worn in the first decade of the century. Laid aside in 1914 it had got the moth. Only out of the tail of her eye did she become aware of something in the reinette apple-tree, a something, a bulk.

With half of her mind she thought, a clump of mistletoe. Mistletoe grew well in the orchard, before this war they had made quite a good sum of money sending mistletoe to England for the Christmas market. Naturally, that was now at an end.

With the other half of her mind she thought that Yves would not live to see another Christmas.

It was odd that she had not noticed so large a clump of mistletoe before. No! It was not so odd. The mistletoe was a man.

A man was entangled in the tree. And now this noise which she had taken to be in her head, for she was rheumatic and suffered considerably from head noises, was plainly the wind fidgeting in an extraordinary sort of drapery that depended from the tree. 
That was it! He had come down by parachute and had entangled himself in the reinette. She had sometimes foreseen such a thing happening, and now it had happened. He might have chosen a better place. She walked up to the tree, treading on swathes of cold silk, waited a little, said, 'Well?'

There was no answer. She put up a hand and took hold of his foot and pulled at it experimentally. It yielded with the meekness of what is newly dead and still in the limbo between the validity of life, the rigidity of death.

She sighed - a sigh of relief. Presently she began to climb into the tree, hauling herself from bough to bough, carefully not touching the young man who reposed lopsidedly in the heart of the old reinette. At last, leaning along a bough, she was able to look down on his face. It was a young face, in no way remarkable until the moon, poking out of her ermine tippet, looked down too, and gave it a romantic intensity and delineated quite clearly the lappet of blood she had first supposed to be a lock of hair.

What a long way to come in order to lie dead in the old reinette! For he was an American.

They needn't have all this good silk, was her next thought. Yards and yards of silk, and that Herr Kummer sending it off to become chemises for his fat daughters in Saxony. A knife! Doubtless the young man would have a knife on him, and that would save her the trouble of going back for a knife from the kitchen. A knife was strapped to his leg ... a long killing knife. He had descended, not to escape death but to inflict it. A piece of metal had interposed between him and his intention. But the others, who had come with him? . . . young men, so armed, coming down by parachute, do not come alone.

Here, beside her in the tree, was the invasion! She began to sidle backwards along the bough, making her way to the ground. Various impulses shook her: to run into hiding, to escape, to hide for her life; to run back to bed and pull the bedclothes over her ears; to run, not to her own bedside, but to that of Kummer's, the knife in her hand. But instead she fell on her knees, leaning her grey head against the lichened 
tree, clinging to its bole with all her force.

It had come, and she dared not receive it. It was too much for her, she was too old, too much disheartened. It had come too late. She could not readjust herself, now, in her seventythird year and in the fourth year of dishonour. She could not readjust herself to liberty. It was too late, she had made her choice and could not unmake it. For one has to choose, and if one is a woman one cannot choose for oneself. There had been Yves, sickly, always dying, asking only to die in peace. There had been the property. There had been the Germans, inescapably victorious, inescapably correct, and appreciating Clo-Clo's talent as his own countrymen had never appreciated it. And there had been Clo-Clo.

'Not that I thought anything of his books,' she exclaimed, addressing the dead soldier's boot. 'All that nonsense about nature and the soil! If he had stayed on the place he'd have learned better. But apparently, it was all he could do.

'And I brought him up, he was like my own child,' she said to the boot.

A child in his forties, still dependent, still needing pocketmoney, still sending home his linen to be washed, his socks to be mended, his dialect passages to be corrected, becomes a burden; and even, it seems, becomes aware of becoming a burden. Clovis had drooped, had pined, had written of the heartlessness of Paris and the quiet of country cemeteries, describing himself wistfully brewing tisanes at midnight and thinking of home. Then, in the van of the forces of occupation, Clovis arrived: flushed, dimpled, annunciatory, a little breathless. 'Like a zephyr,' as Yves remarked. At last, he said, embracing her, at last he was in a position to show his gratitude. Henceforth she and Uncle Yves could depend on him.

'It will be difficult to transport Yves,' she had said. 'He went to England once, a town called Worthing, and disliked it.'

The zephyr stiffened. It was not, he explained, a question of flight, and above all not a question of England. The hour had struck for France to embrace her new career as a collaborator in the new Europe. His dear relations would continue to live quietly on their property, setting an example. 
Honour, comfort, revenue, would flow to them, and he himself would visit them whenever his duties allowed it. For he would be immensely occupied. But even when he could not visit them personally his voice would reach them on the Radio.

'It seems you have everything arranged,' said Yves.

Clo-Clo flickered his hand.

'It is a little in the air. It would be better if you don't talk of it just yet. But the essentials are arranged.'

'I don't like it.' She had said that.

He turned pale, his lips trembled, his eyes became the eyes of a calf dragged to the butcher.

'My career . . ' His voice rose. 'After all these years of being slighted, of being kept down and reviewed in corners, my career opens. They appreciate me, I tell you. They know my work. They are going to re-issue me in a collected edition. Are you going to wreck me? Now?'

While she had hesitated, confused and in anguish, Yves, rearranging the rug over his legs, remarked that it would scarcely be worth it.

'And so ... and so,' she murmured, staring at the boot.

So close above her head the boot was enormous. It seemed about to descend, to crush her. Birds flew in and out of the trees, the day was coming, every moment the drapery of the parachute grew paler and its folds more distinct, and she saw that some of it was charred with fire. Holding to the trunk of the old reinette she clambered stiffly to her feet. There was an apple-spray in her hand, for a long time she had been clutching it unconsciously. Now she became aware of it. It was crushed, sodden, done for. She opened her hand and let it fall. Clo-Clo's flourishing career, Clo-Clo himself, and Yves, and she, a flourish put out from an old tree, all done for in this early morning.

She looked at the dead man. He was distinct now, in an hour or so the flies would come buzzing about him. She gave - a courtesy - a thought to the woman who had reared him as she had reared Clovis. A convulsion of misery shook her, but she was scarcely aware of it for in the same moment the air was convulsed by the vibration of heavy gunfire. The 
parachute fluttered as if it were coming to life. Immature fruit pattered down. It was beginning It was ending! From long ago, from Paris and her year at the finishing school and the visits in muslin to the Comedie Francaise, the words, the declamation, the attitude came back to her.

Arsace, il faut partir quand j'aurai vu la reine.

Her cracked voice rang out. She seemed to be standing on an enormous stage. Then, walking rigidly under the tumult of the naval bombardment, she went back to the house. 